\title{
Accounting Scandals And Stock Performance: Life After Enron
}

Matiur Rahman, McNeese State University, USA

Daryl V. Burckel, McNeese State University, USA

Muhammad Mustafa, South Carolina State University, USA

\begin{abstract}
This paper studies the effects of earnings restatements of selected ten U. S. companies by implementing the event study methodology. The effects are asymmetric across these companies as they are heterogenous in terms of industry classifications. The effects are also conditional upon the fraud and coming-out-clean perceptions about them. Additionally, the effects are dependent on the demand prospects for their products and services.
\end{abstract}

Keywords: Earnings Restatements, Event Study, Cumulative Abnormal Return, Market Portfolio, CAPM

\section{INTRODUCTION}

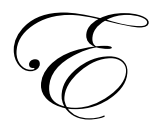

nron became a legend of global corporate success over a short span of time. But its quick success was an overstatement, to say the least. Enron operated in the United States, Canada, Europe, Japan,

Australia, South America and India. Their activities were in transportation and distribution, wholesale services, retail energy services, broadband services, and other sectors with wholesale services accounting for 93 percent of 2000 revenues. On October 16, 2001, Enron announced its third quarter 2001 net loss of $\$ 618$ million and on November 8, 2001 announced that it would restate earnings for 1997 through 2001. The restatement reported net losses of \$96 million in 1997, \$113 million in 1998, \$250 million in 1999 and \$132 million in 2001. The increases in consolidated debt rose $\$ 711$ million in 1997, \$561 million in 1998, \$685 million in 1999, and \$628 million in 2001. On December 2, 2001, Enron and 13 of its subsidiaries filed for Chapter 11 bankruptcy protection under the federal bankruptcy code. From May 2001, Enron's stock price fell from $\$ 60$ to $\$ 9$ on November 28, 2001. Afterwards, the stock price dropped further to $\$ 0.16$ as of September 13, 2002. Enron, after its demise, is now a dark chapter in the U.S. corporate history.

Since the fall of Enron, many of public companies have revealed their accounting scandals, financial irregularities and financial fraud shocking academicians, practitioners and stock market participants. They restated their quarterly statements in an attempt to restore investors' trust, but the impacts on their stock prices said just the opposite. Continuous negative information through the print and electronic news media drew the attention of the Securities Exchange Commission (SEC), Department of Justice and the General Accounting Office (GAO). After lengthy Congressional hearings and investigative reports by regulatory agencies, Congress enacted the SarbanesOxley Act of 2002. The Act focused on strengthening corporate governance, improving transparency and accountability in order to ensure the accuracy and integrity of the financial reporting system.

Restated earnings often result in a serious downward movement in a company's stock price. Other consequences of financial restatements include a perception of incompetence or fraud, a downward revision of expected future cash flows, increased litigation risk, increased cost of capital, and downgraded credit ratings. There were 1,010 restating companies as of March 2005 since the fall of Enron. Those companies hoped that earnings restatements would allow them to come clean and provide investors with corrected information to make investing decisions. While a restatement may appear to be a solution to a problem, it may create as many problems as it solves. In short, undoing past financial accounting mistakes is both difficult and costly. 
This paper examines the likely effects of earnings restatements, of 10 selected companies, on their stock prices by employing the event study methodology. The companies include Adelphia, JDS Uniphase Corporation, MicroStrategy Incorporated, Orbital Sciences Corporation, Rite Aid Corporation, Shurgard Storage Centers Inc., Thomas and Betts Corporation, Waste Management Inc., and Xerox Corporation. The remainder of the paper is organized as follows. Section II reviews the relevant literature. Section III outlines the event study methodology. Section IV reports empirical results. Finally, section V offers conclusions.

\section{REVIEW OF RELATED LITERATURE}

The efficient market hypothesis (EMH) that has been the cornerstone of modern financial reporting has come under closer academic scrutiny since 2001 due to opaque accounting practices by numerous large corporations. A growing body of studies' has focused on the event of earnings restatement. Palmrose et. al. (2004) and $\mathrm{Wu}(2002)$ document that stock prices react negatively by about $10 \%$ during the two days surrounding accounting restatement announcements. Ikenberry and Ramnath (2002) describe a class of self-selected corporate news events (IPO, cash distributions, and stock splits) that management uses on discretion to take advantage of the "window of opportunity".

Contrary to self-selected events, earning restatements are usually externally initiated. The event of an earnings restatement exposes the severity of credibility gap (Desi et al., 2004; Richardson et al., 2003), followed by high probability of lawsuits (Palmrose and Scholz, 2003; Jones and Weingram, 1997), management shuffling (Desi et al, 2004), difficulties in raising capital (Hribar and Jenkins, 2003), higher monitoring costs (Palmrose et al., 2004) and even bankruptcy (Palmrose et al., 2004). One may also view the announcement of an accounting restatement as a clarifying event. When earnings restatements are announced, it is not known if the consequences of the negative impact of such an event are fully anticipated by investors. An answer to this question should shed light on the nature of accounting information and how capital markets incorporate that information into the value of the security. Additionally, in recent years there has been an increased attention to the quality of reported earnings (Levitt, 2000).

Richardson, Sloan, and Tuna (2002) find that accrual information is a key determinant of the earnings manipulation. Heightened capital market pressure has created an additional incentive for firms to engage in earnings manipulation (Myers and Skinner, 2002; Barth, Elliot and Finn, 1999) and beat analyst targets (Burgstahler and Eames, 2001; DeGeorge, Patel and Zeckhauser, 1999). Myers and Skinner (2002), and Barth Elliot and Finn (1999) also report strong evidence of negative market reactions to firms that break strings of earnings increases.

\section{EMPIRICAL METHODOLOGY}

Event studies methodology pioneered perhaps in Dolley (1933) is implemented for this study to capture the price effects of announcements which occur after the stock market closes on the announcement day. The initial task of conducting an event study is to define the event of interest and to identify the period over which the security prices of the firms involved in this event is examined - the event window. It is customary to define the event window to be larger than the specific period of interest. This paper uses daily data and includes the event window period of \pm 20 days around the earnings restatement announcement date. The parameters of the market model are estimated over the 20 days prior to the event. The event period itself is not included in the estimation period to prevent the event from influencing the normal performance model parameter estimates. With the parameter estimates for the normal performance model, the abnormal returns are calculated. The Empirical results are expected to lead to insights relating to understanding the sources and causes of the effects (or lack of effects) of the event under study (Mackinlay, 1997).

The market model is used in this paper that relates the return of any given security to the market portfolio. Assuming joint normality of asset returns, the estimating model's linear specification is as follows:

$\mathrm{R}_{\mathrm{it}}=\alpha_{\mathrm{i}}+\beta_{\mathrm{i}} \mathrm{R}_{\mathrm{mt}}+\varepsilon_{\mathrm{it}}$

$\mathrm{E}\left(\varepsilon_{\mathrm{it}}=0\right)$ and $\operatorname{Var}\left(\varepsilon_{\mathrm{it}}\right)=\delta_{\mathrm{it}}^{2}$ 
Where $R_{i t}$ and $R_{m t}$ are the period - $t$ returns on security $i$ and the market portfolio (S\&P500), respectively, and $\varepsilon_{i t}$ is the zero mean disturbance term. $\alpha_{\mathrm{i}}, \beta_{\mathrm{i}}$ and $\delta_{\mathrm{it}}{ }^{2}$ are the parameters of the market version of CAPM (Sharpe, 1964; and Lintner, 1965).

The model is estimated by the ordinary least squares (OLS) to obtain the parameters using data for 20 business days prior to the event date. The parameters $\left(\hat{\alpha}_{i}\right.$ and $\left.\hat{\beta}_{i}\right)$ are used to estimate the rates of return for each day including the event date. Altogether, there will be a column for 41 rates of return $( \pm 20$ days + event date). The abnormal returns $\left(\mathrm{AR}_{\mathrm{it}}\right)$ for the entire sample period are then computed as follows:

$$
\mathrm{AR}_{\mathrm{it}}=\mathrm{R}_{\mathrm{it}}-\hat{\alpha}_{\mathrm{i}}-\hat{\beta}_{\mathrm{i}} \mathrm{R}_{\mathrm{mt}}
$$

The abnormal returns are assumed to be jointly normally distributed with a zero conditional mean and conditional variance.

Under the null hypothesis $\left(\mathrm{H}_{\mathrm{o}}\right)$ that the event has no impact on the behavior of returns (mean or variance) the distributional properties of the abnormal returns are used to draw inferences over the period within the event window. The sample abnormal return of a given observation in the event window is:

$$
\mathrm{AR}_{\mathrm{it}} \sim \mathrm{N}\left(\mathrm{O}, \delta^{2}\left(\mathrm{AR}_{\mathrm{it}}\right)\right)
$$

Equation (3) is built upon to consider the aggregation of the abnormal returns. This is essential to draw overall inferences for the event of interest through time/or across securities. The cumulative abnormal returns (CAR's) are obtained security by security by aggregating the abnormal returns obtained from equation (2). The relative stability of the CAR plots is then visually inspected by using the chartist approach.

\section{RESULTS}

As the companies are heterogeneous in terms of products and services, nature of problems and announcement dates (Appendix-I), the companies have been treated individually instead of aggregating them together. The following table presents pre-announcement, announcement day and post-announcement cumulative abnormal returns.

\begin{tabular}{|c|c|c|c|}
\hline Company & $\begin{array}{c}\text { Pre-announcement period } \\
\left(t_{-20} \text { to } t_{-1}\right)\end{array}$ & $\begin{array}{c}\text { Announcement date } \\
\left(t_{0}\right)\end{array}$ & $\begin{array}{c}\text { Post-announcement period } \\
\left(t_{+1} \text { to } t_{+20}\right)\end{array}$ \\
\hline Adelphia & $6.08 \%$ to $38.73 \%$ & $22.29 \%$ & $13.48 \%$ to $-23.6 \%$ \\
\hline Critical Path, Inc. & $1.81 \%$ to $2.58 \%$ & $-5.73 \%$ & $-30.78 \%$ to $24.91 \%$ \\
\hline JDS Uniphase Corp. & $-4.57 \%$ to $-3.69 \%$ & $7.64 \%$ & $16.96 \%$ to $38.40 \%$ \\
\hline Microstrategy Inc. & $-9.38 \%$ to $-48.46 \%$ & $-53.47 \%$ & $-58.18 \%$ to $-87.8 \%$ \\
\hline Orbital Sciences & $1.23 \%$ to $-31.54 \%$ & $-33.70 \%$ & $-40.05 \%$ to $-61.34 \%$ \\
\hline Rite Aid Corp. & $9.92 \%$ to $19.71 \%$ & $-1.28 \%$ & $-11.22 \%$ to $-41.56 \%$ \\
\hline Shurgard Storage Centers & $-0.55 \%$ to $-4.91 \%$ & $-9.59 \%$ & $-8.39 \%$ to $-6.44 \%$ \\
\hline Thomas and Betts Corp. & $-0.59 \%$ to $1.93 \%$ & $-1.29 \%$ & $-3.18 \%$ to $0.16 \%$ \\
\hline Waste Management, Inc. & $-1.04 \%$ to $-.55 .22 \%$ & $-56.44 \%$ & $-64.66 \%$ to $-54.09 \%$ \\
\hline Xerox Corporation & $3.80 \%$ to $-4.14 \%$ & $4.63 \%$ & $10.89 \%$ to $-4.47 \%$ \\
\hline
\end{tabular}

Table 1: Cumulative Abnormal Return

As observed above, Adelphia was enjoying positive and improving stock performance during the postannouncement period, but it deteriorated during the post-announcement period entering into negative territory. This was perhaps due to Adelphia's inability to undo the past completely. However, its stock performance was relatively less dismal because of the strong demand prospects for its services and its untangling from fraud-perception. 
The stock performance of the Critical Path Corporation was depressing during the post-announcement period as compared to the pre-announcement period, but recovered significantly toward the end of the post-event window. This was attributable to the strong demand prospects for its products and lack of customers' fraud perception.

- $\quad$ JDS Uniphase Corporation made a surprisingly strong comeback in the post-announcement period because of strong demand prospects for its products and its ability to project a positive image by its act of clearing the past accounting misdeeds.

- Microstrategy Inc. was hit hardest during the post-announcement period because it was associated with fraud and lackluster demand for its services.

- Orbital Sciences was also badly affected during the post-announcement period because of its distorted image and a lack of demand for its products.

- $\quad$ Rite Aid fared very poorly during the post-announcement period because of its fraudulent accounting practices and failure to be competitive with its rival firms.

- Shurgard Storage Centers Corporation was badly affected on a moderate scale both during preannouncement and post-announcement periods because of relatively healthy real estate market at that time and absence of fraud perception in the minds of its customers.

- $\quad$ Thomas and Betts Corporation was affected marginally during the post-announcement period. But it was able to recover fully later on because of surging demand for its products and absence of fraud perceptions.

- Waste Management Corporation was also very badly affected during the post-announcement period because of fraud, improper conduct and shareholder lawsuit.

- $\quad$ The effect on Xerox Corporation was marginally negative during the post-announcement period because it was charged with violations of Securities Exchange Act instead of fraud and manipulations. Moreover, the demand for its products was expected to be strong. Appendix-II.

The visual effects of earnings restatements on the above accompanies are presented graphically in

\section{CONCLUSIONS}

The effects of earnings restatements on the individual companies are asymmetric because of the heterogeneities in their products and services including the demand for their products. The effects are also conditional upon the customers' perception about the company whether it was engaged in fraud or striding to come clean after undoing the past misdeeds. Accordingly, the companies are either rewarded or punished by their distinct markets.

\section{AUTHOR INFORMATION}

Dr. Matiur Rahman is a professor of finance at McNeese State University. He has published numerous articles on various economics and finance topics in journals in the U.S.A. and abroad.

Dr. Daryl V. Burckel is a professor of accounting at McNeese State University. He published numerous articles. His specialization is in federal taxation.

Dr. Muhammad Mustafa is a professor of economics. He is an avid researcher and published extensively in finance and economics.

\section{REFERENCES}

1. Barth, M. E., J. A. Elliot and M. W. Finn, Market Rewards Associated with Patterns of Increasing Earnings, Journal of Accounting Research, 37, 387-413, 1999.

2. Burgstahler, D., and M. Eames, Management of Earnings and Analysts' Forecasts. Working Paper, University of Washington, Seattle, WA, 2001. 
3. DeGeorge, F., J. Patel, and R. Zeckhauser, Earnings Management to Exceed Thresholds, Journal of Business, 72, 1-33, 1999.

4. Desai, H., Krishnamurthy, S., and Venkataraman, K, Do Short Sellers Target Firms with Poor Earnings Quality?: Evidence from Earnings Restatements, Southern Methodist University, Working Paper, 2004.

5. Dolley, James Clay, Characteristics and Procedure of Common Stock Split-ups, Harvard Business Review, 11, 316-326, 1933.

6. Hribar, P. and Jenkins, N.T., The Effect of Accounting Restatements on Earnings Revisions and the Estimated Cost of Capital, Cornell University, Working Paper, 2003.

7. Ikenberry, D. L., and S. Ramnath, Underreaction to Self-selected News Events: The Case of Stock Splits, The Review of Financial Studies 15, No 2, 489-526, 2002.

8. Jones, C. L. and E. Weingram, The Effects of Insider Trading, Seasoned Equity Offerings, Corporate Announcements, Accounting Restatements, and SEC Enforcement Action 10b-5 Litigation Risk, Stanford University, Graduate School of Business Working Paper Series, 1997.

9. Levitt, A, Testimony Concerning Commission's Auditor Independence Proposal before the Senate Subcommittee on Securities Committee on Banking, Housing, and Urban Affairs. September 28, 2000. http://www.sec.gov/news/testmony/ts152000.htm., 2000.

10. Linter, John, The Valuation of Risky Assets and the Selection of Risky Investment in Stock Portfolios and Capital Budgets, Review of Economics and Statistics, 47, 13-37, 1965.

11. MacKinlay, A. Craig, Event Studies in Economics and Finance, Journal of Economic Literature, XXXV, 13-39, 1997.

12. Myers, L., and D. Skinner, Earnings Momentum and Earnings Management, Working Paper, University of Michigan, 2002.

13. Palmrose, Z-V, V.J. Richardson, and S. Scholz, Determinants of Market Reactions to Restatement Announcements, Journal Accounting and Economics, 37, 59-89, 2004.

14. Palmrose, Z-V., S. Scholz, The Circumstances and Legal Consequences of Non-GAAP Reporting: Evidence from Restatements, Contemporary Accounting Research, 139-178, 2003.

15. Richardson, S., R. Sloan, M. Soliman and I. Tuna, Information and Accruals about Earnings Persistence and Future Stock Returns, Working paper, University of Michigan, 2002.

16. Sharpe, William F, Capital Asset Prices: A Theory of Market Equilibrium Under Conditions of Risk, Journal of Finance, 19, 425-442, 1964.

17. Wu, Min, Earnings Restatements: A Capital Market Perspective, New York University, Ph. D. Dissertation, 2002. 
APPENDIX-I

\begin{tabular}{|c|c|c|c|c|}
\hline \multicolumn{5}{|c|}{ Summary of Earnings Restating Companies } \\
\hline Companies & $\begin{array}{c}\text { Announcement } \\
\text { Date }\end{array}$ & Products/Services & Reasons & Stock Price* \\
\hline 1.Adelphia & $3 / 27 / 02$ & $\begin{array}{l}\text { Entertainment and } \\
\text { Communication Services }\end{array}$ & $\begin{array}{l}\text { False and misleading } \\
\text { statement about debt levels } \\
\text { and off-balancesheet debt, and } \\
\text { shareholder class-action suit }\end{array}$ & $\$ 20.39 \rightarrow \$ 6.05$ \\
\hline 2. Critical Path & $4 / 5 / 01$ & $\begin{array}{l}\text { Internet messaging and } \\
\text { infrastructure products and } \\
\text { services }\end{array}$ & $\begin{array}{l}\text { Violation of federal and } \\
\text { securities laws and suit by } \\
\text { shareholders }\end{array}$ & $\$ 116.75 \rightarrow \$ 0.26$ \\
\hline 3. JDS Uniphase & $9 / 19 / 01$ & $\begin{array}{l}\text { Fiber-optic components, } \\
\text { modules and subsystems } \\
\text { for fiber-optics } \\
\text { communication industry }\end{array}$ & $\begin{array}{l}\text { Violations of Securities } \\
\text { Exchange Act of } 1934 \text { and } \\
\text { civil class-action suit }\end{array}$ & $\$ 105.59 \rightarrow \$ 3.34$ \\
\hline 4. Microstrategy & $4 / 13 / 00$ & $\begin{array}{l}\text { Business Intelligence } \\
\text { Software }\end{array}$ & $\begin{array}{l}\text { False and misleading } \\
\text { statements about financial } \\
\text { results and class-action suit }\end{array}$ & $\$ 72.31 \rightarrow \$ 0.47$ \\
\hline 5. Orbital Sciences & $2 / 16 / 99$ & Space technology & Shareholders class-action suit & $\$ 45 \rightarrow \$ 2.25$ \\
\hline 6. Rite Aid & $7 / 11 / 00$ & $\begin{array}{l}\text { Prescription drugs, non- } \\
\text { prescription medications, } \\
\text { health and beauty aids, } \\
\text { photo processing, } \\
\text { convenience items, } \\
\text { cosmetics and personal care } \\
\text { items }\end{array}$ & $\begin{array}{l}\text { False and misleading } \\
\text { statements, artificial inflating } \\
\text { of stock prices, and securities } \\
\text { class-action suit }\end{array}$ & $\$ 50 \rightarrow \$ 3.06$ \\
\hline 7. Shurgard Storage & $11 / 8 / 01$ & $\begin{array}{l}\text { Real estate investment and } \\
\text { self-storage }\end{array}$ & $\begin{array}{l}\text { Moody's and S\&P's } \\
\text { downgrading of unsecured } \\
\text { debt and preferred stocks }\end{array}$ & $\$ 30.76 \rightarrow \$ 29.38$ \\
\hline 8. Thomas and Betts & $8 / 21 / 00$ & $\begin{array}{l}\text { Electrical Components and } \\
\text { Systems }\end{array}$ & $\begin{array}{l}\text { Violations of Securities } \\
\text { Exchange Act, Shareholder } \\
\text { class-action suit }\end{array}$ & $\$ 53 \rightarrow \$ 0.74$ \\
\hline 9. Waste Management & $8 / 21 / 00$ & $\begin{array}{l}\text { Integrated Waste } \\
\text { Management Services } \\
\text { (Collection, transfer, } \\
\text { disposal, recycling) and } \\
\text { resource recovery services }\end{array}$ & $\begin{array}{l}\text { Fraud, improper conduct and } \\
\text { shareholder lawsuit }\end{array}$ & $\$ 60 \rightarrow \$ 15$ \\
\hline 10. Xerox Corporation & $5 / 32 / 01$ & $\begin{array}{l}\text { Electrical components and } \\
\text { systems }\end{array}$ & $\begin{array}{l}\text { Violations of Securities } \\
\text { Exchange Act, Shareholder } \\
\text { class-action suits }\end{array}$ & $\$ 53 \rightarrow \$ 0.74$ \\
\hline
\end{tabular}

\footnotetext{
*Stock price on the announcement day and then the lowest price in the post-event window
} 


\section{APPENDIX-II}

\section{Adelphia Communications Corporation (ADELQ)}

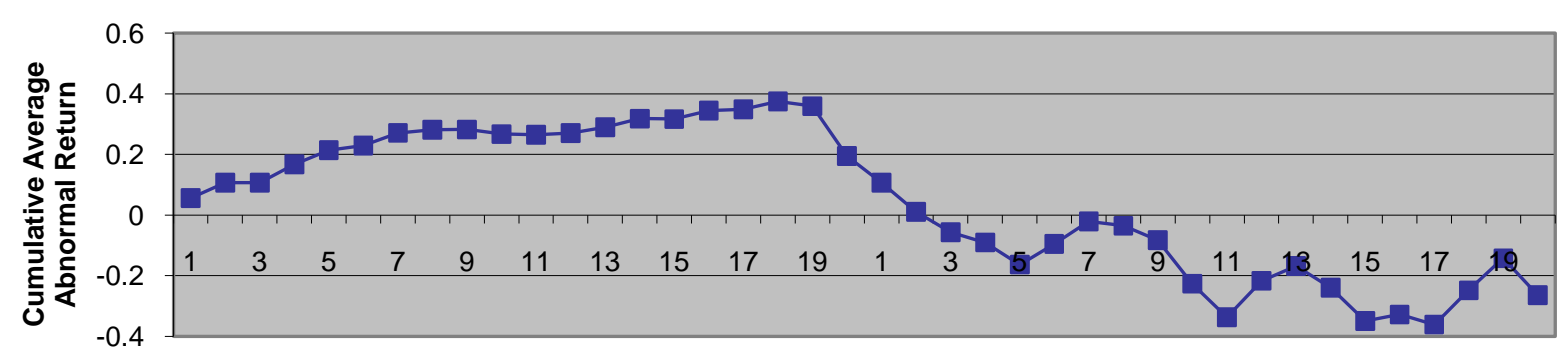

Days Relative to Announcement Date

Critical Path, Inc. (CPTH)

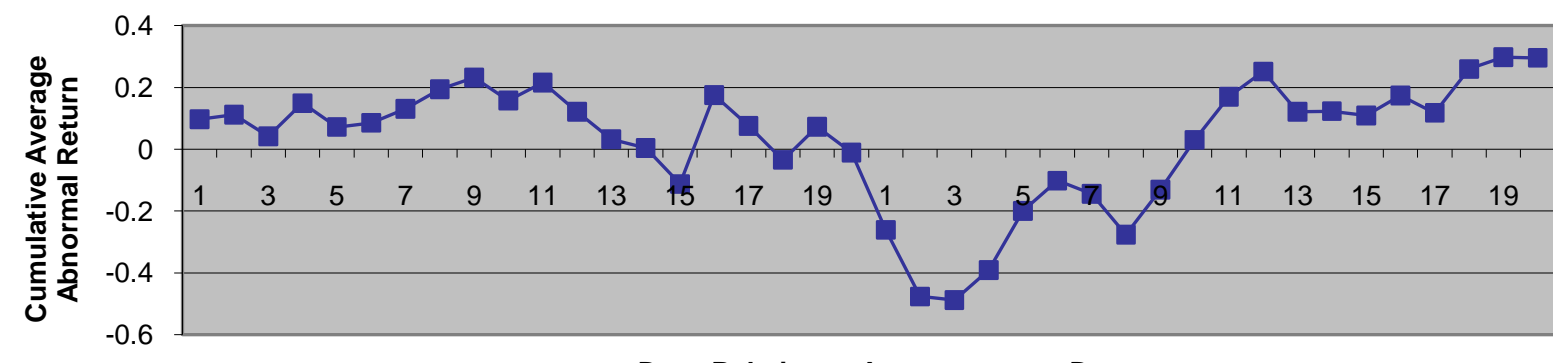

Days Relative to Announcement Date

JDS Uniphase Corporation (JDSU)

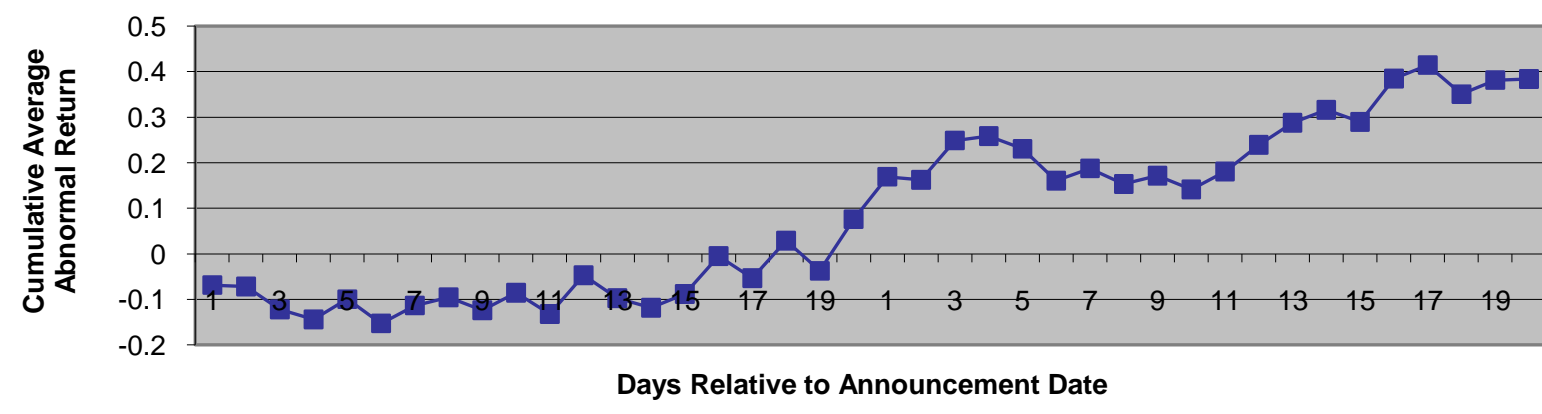

Microstrategy Incorporated (MSTR)

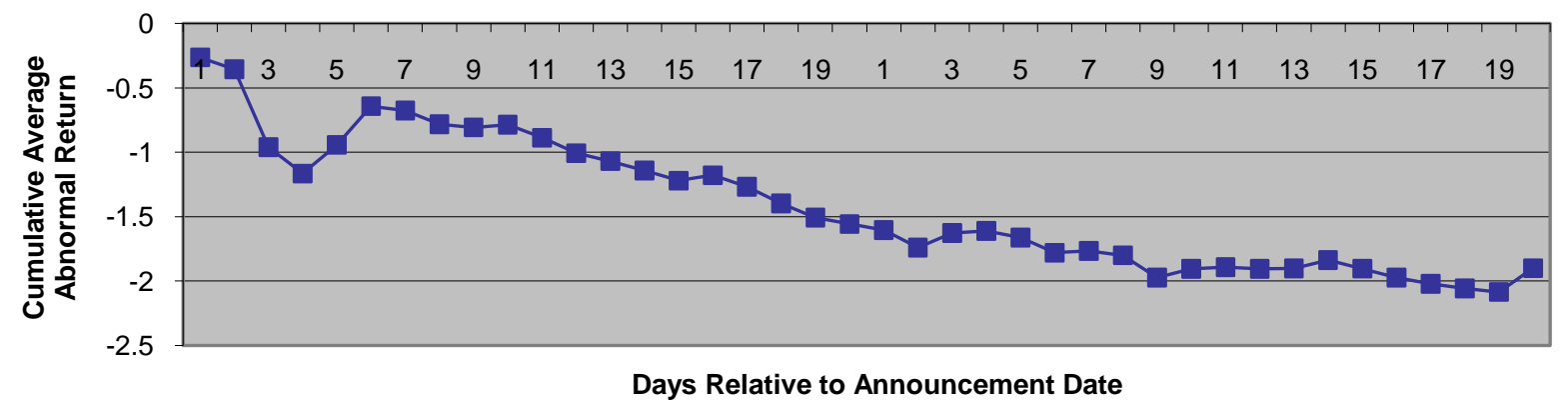




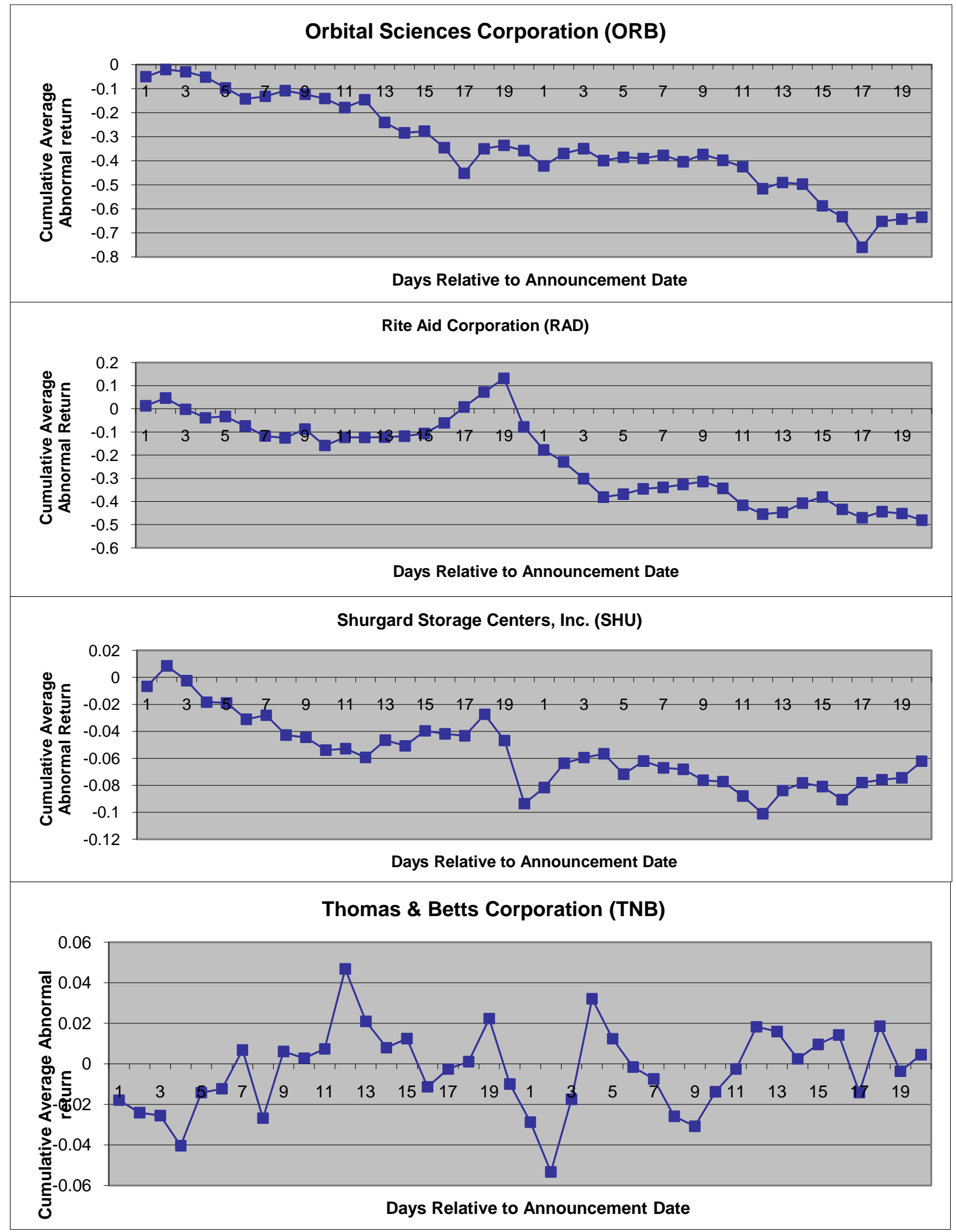




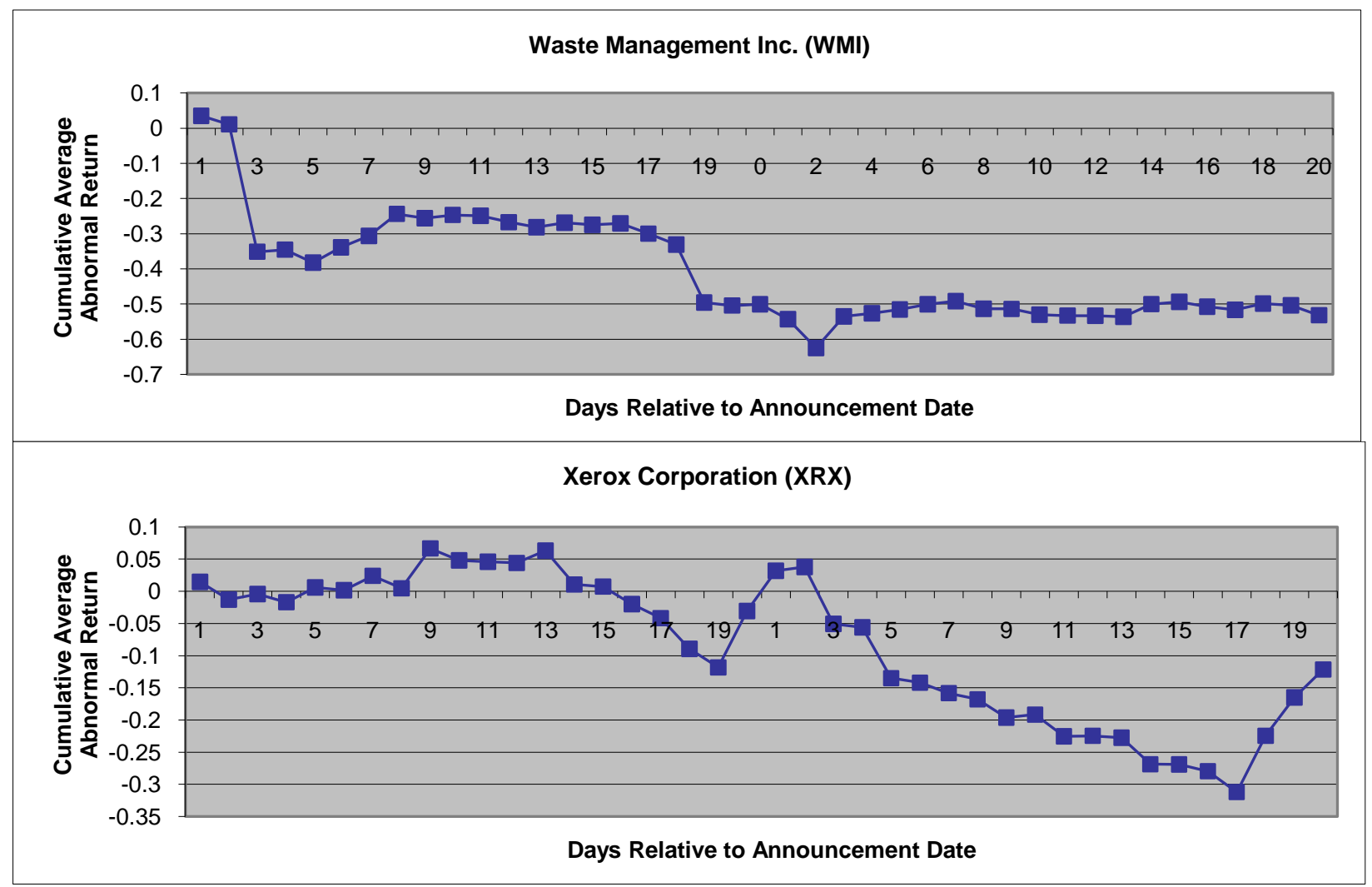




\section{NOTES}

